\title{
Influence of Peri-Implant Soft Tissue Condition and Plaque Accumulation on Peri-Implantitis: a Systematic Review
}

\author{
Mindaugas Pranskunas ${ }^{1}$, Lukas Poskevicius ${ }^{1}$, Gintaras Juodzbalys ${ }^{1}$, Ricardas Kubilius ${ }^{1}$, \\ Ryo Jimbo ${ }^{2}$ \\ ${ }^{1}$ Department of Maxillofacial Surgery, Lithuanian University of Health Sciences, Kaunas, Lithuania. \\ ${ }^{2}$ Department of Oral and Maxillofacial Surgery and Oral Medicine Faculty of Odontology, Malmö University, Sweden.
}

\author{
Corresponding Author: \\ Mindaugas Pranskunas \\ Basanaviciaus al. 58-8, LT-50195, Kaunas \\ Lithuania \\ Phone: +37065941955 \\ E-mail: mindaugaspranskunas@hotmail.1t
}

\begin{abstract}
Objectives: To systematically examine influence of soft tissue condition and plaque accumulation around dental implants on peri-implantitis development.

Material and Methods: An electronic literature search was conducted of two databases - MEDLINE (Ovid) and EMBASE from 2011 to 2016. Sequential screenings at the title, abstract, and full-text levels were performed. Clinical human studies in the English language that had reported soft tissue condition or plaque accumulation influence on peri-implantitis development were included. The resulting articles were independently subjected to clear inclusion and exclusion criteria by two reviewers as follows.

Results: The search resulted in 8 articles meeting the inclusion criteria. These studies reported gingival index, plaque index, pocket depth, bleeding on probing/modified bleeding index for sites with "adequate" $(\geq 2 \mathrm{~mm})$ and "inadequate" $(<2 \mathrm{~mm})$ width of keratinized mucosa. Results demonstrated that the amount of keratinized mucosa has little influence on soft-tissue inflammation in the presence of good oral hygiene. However, suboptimal oral hygiene due to difficulty in access for plaque control in the areas of minimal keratinized mucosa may lead to greater tissue damage.

Conclusions: In cases with insufficient keratinized gingiva in the vicinity of implants, the insufficiency does not necessarily mediate adverse effects on the hygiene management and soft tissue health condition. Nonetheless, the risk of the increase of gingival index, plaque index, pocket depth, bleeding on probing/modified bleeding index is present. Therefore, the presence of an appropriate amount of keratinized gingiva is required.
\end{abstract}

Keywords: dental implants; dental plaque; gingiva; peri-implantitis; risk factors.

Accepted for publication: 7 September 2016

To cite this article:

Pranskunas M, Poskevicius L, Juodzbalys G, Kubilius R, Jimbo R.

Influence of Peri-Implant Soft Tissue Condition and Plaque Accumulation on Peri-Implantitis: a Systematic Review

J Oral Maxillofac Res 2016;7(3):e2

URL: http://www.ejomr.org/JOMR/archives/2016/3/e2/v7n3e2.pdf

doi: $10.5037 /$ jomr.2016.7302 


\section{INTRODUCTION}

Periodontitis can be considered as the consequence of broken balances in bacterial components of the dental plaque [1]. Its prevalence drives to its consideration as the most prevalent infectious disease in the community [2], with $75 \%$ of adults affected as reported in published studies $[\underline{3}, \underline{4}]$. Several studies have identified similarities in the pathogenesis of late periodontitis and peri-implantitis, showing intraoral translocation of periodontal pathogens from teeth showing chronic periodontitis to the peri-implant niche [5], producing at last the loss of affected teeth or implants. Previous history of periodontitis, poor oral hygiene and smoking are considered risk factors for peri-implantitis, and late dental implant failures are associated with peri-implantitis and/or biomechanical forces [6]. While peri-implantitis is defined on implant basis (an inflammatory process leading to deformation of the peri-implant pocket and bone loss around an implant in function) [7], periodontitis is defined on subject basis (individuals with more than one tooth [] showing alterations not only in the classical measures of bone loss but also in additional parameters as bleeding on probing and probing pocket depth) [9].

The peri-implant keratinized mucosa is firmly bound to the underlying bone and constitutes a functional barrier between the oral environment and underlying dental implants. However, after teeth are extracted, the resorption of surrounding bone and keratinized gingiva occurs, which may result in deficiency of keratinized mucosa during subsequent implant placement. The need for keratinized mucosa around dental implants has been widely discussed. During the early development of endosseous dental implants, the establishment of a dense connective tissue around the implant collar for long-term implant stability was repeatedly addressed [10-12]. Nevertheless, a number of subsequent studies showed that implants had a high survival rate irrespective of the presence or absence of keratinized mucosa [13]. Nowadays, in addition to achieving high implant survival following implant therapy, maintenance of functionally loaded implants in an adequate status of health and aesthetics had become a prerequisite for long-term success of implant restoration. The need for keratinized tissue around the dental implant to maintain health and tissue stability is therefore becoming of increasing concern.

Because of the vast differences between natural teeth and dental implants, their maintenance is of critical importance for the longevity of successful osseointegrated implants. A study which purposely banned oral hygiene around dental implants for a short period of time demonstrated a cause-effect relationship between the accumulation of bacterial plaque and the development of peri-implant mucositis [14]. Recent studies have shown that bacterial colonization occurs within 30 minutes following implantation [15] and becomes stable after a 2-week period $[\underline{16}, \underline{17}]$. Thus, the primary objective of maintenance and recovery of any implant regiment is to remove the bacterial plaque and/or calculus.

Of course, the dental provider has a role in guiding implant stability following osseointegration, however, proper maintenance of the peri-implant soft tissue health is largely in the control of the patient's own oral hygiene regimen. Patients' self-management includes mechanical methods and chemical ways to control biofilm formation and subsequent plaque/ calculus accumulation.

Therefore, the aim of the present study is to determine influence of soft tissue condition and plaque accumulation around dental implants on periimplantitis development.

\section{MATERIAL AND METHODS Protocol and registration}

The methods of the analysis and inclusion criteria were specified in advance and documented in a protocol. The review was registered in PROSPERO, an international prospective register of systematic reviews.

The protocol can be accessed at:

http://www.crd.york.ac.uk/PROSPERO/display record.asp?ID=CRD42016033672

Registration number: CRD42016033672.

The reporting of this systematic analysis adhered to the PRISMA Statement [18].

\section{Types of publications}

The review included studies on humans published in the English language. Letters, editorials, literature reviews, $\mathrm{PhD}$ theses, and abstracts were excluded.

\section{Types of studies}

The review included all human prospective and retrospective follow-up studies and clinical trials, cohort studies, case-control studies, and case series studies published between January 2011 and March 2016, on various soft-tissue conditions and plaque accumulation around dental implant influence on 
peri-implantitis development. Case report studies were excluded.

\section{Information sources}

The search strategy incorporated examinations of electronic databases, supplemented by hand searches. A search was conducted on two databases - MEDLINE (Ovid) and EMBASE. Additionally, a hand search was carried out in dental implant related journals, including "Journal of Oral and Maxillofacial Implants", "Clinical Oral Implants Research", "European Journal of Oral Implantology", "Journal of Oral and Maxillofacial Surgery", "Journal of Clinical Periodontology", "Journal of Periodontology", "International Journal of Oral and Maxillofacial Surgery", "The International Journal of Periodontics and Restorative Dentistry". The references of each relevant study were screened to discover additional relevant publications and to improve the sensitivity of the search.

\section{Search}

The MEDLINE and EMBASE resource databases were explored through advanced searches. The keywords and search inquiries that were used during the primary stage were as follows: (("attached gingiva" OR "keratinized gingiva" OR "keratinized mucosa" OR "attached mucosa" OR "soft tissue condition" OR "soft tissue volume" OR "gingiva volume" OR "soft tissue height" OR "gingiva height" OR "soft tissue width" OR "gingiva width")) AND ("peri-implantitis" OR "peri-implant pathology" OR "dental implant infections" OR "peri-implant bone loss" OR "peri-implant disease") OR (("plaque" OR "plaque accumulation" OR "plaque index" OR "plaque control")) AND ("peri-implantitis" OR "periimplant pathology" OR "dental implant infections" OR peri-implant bone loss" OR "peri-implant disease").

The choice of keywords was intended to be broad, in order to collect as much relevant data as possible without relying on electronic means alone to refine the search results.

\section{Selection of studies}

The resulting articles were independently subjected to clear inclusion and exclusion criteria by two reviewers as follows. Reviewers compared decisions and resolved differences through discussion, consulting a third party when consensus could not be reached. The third party was an experienced senior reviewer.

\section{Inclusion and exclusion criteria}

The applied inclusion criteria for studies were as follows:

- Investigated soft-tissue dimensions at implant sites and peri-implantitis occurrence;

- Followed-up plaque accumulation influence on peri-implantitis development;

- All human prospective or retrospective follow-up studies and clinical trials, cohort studies, casecontrol studies, and case series studies with at least 5 patients;

- A follow-up time period of at least 6 months after the placement of definitive prosthesis;

- Could not be excluded before careful reading.

The following articles were excluded:

- Studies that targeted soft-tissue condition around teeth;

- Studies where the effect of soft tissue condition and plaque accumulation on peri-implantitis could not be extracted from the data (e.g., a combination of other risk factors, including heavy smokers, systemic diseases, personal habits);

- Studies that included unclear data, with authors who could not be contacted for any reason.

\section{Sequential search strategy}

Following the initial literature search, all article titles were screened to eliminate irrelevant publications, review articles, case reports, and animal studies. Next, studies were excluded based on data obtained from screening the abstracts. The final stage of screening involved reading the full texts to confirm each study's eligibility, based on the inclusion and exclusion criteria.

\section{Data extraction}

The data were independently extracted from studies in the form of variables, according to the aims and themes of the present review, as listed onwards.

\section{Data items}

Data were collected from the included articles and arranged in the following fields: year, follow-up period, patient number, implant number, plaque index, gingiva index, probing depth.

\section{Assessment of methodological quality}

The risk of bias assessment of the included trials was undertaken independently and in duplicate by at least two review authors as part of the data extraction process. 
This was conducted using the recommended approach for assessing risk of bias in studies included in Cochrane reviews [19].

\section{Synthesis of results}

Relevant data of interest on the previously stated variables were collected and organised into table.

\section{Statistical analysis}

No meta-analyses could be performed due to the heterogeneity between the studies.

\section{RESULTS \\ Study selection}

Article review and data extraction were performed according to the PRISMA flow diagram. The initial search identified a total of 1071 articles. Following the screening of the article titles, 543 potentially relevant articles were identified. Independent screening of the abstracts resulted in the selection of 46 publications for possible inclusion. The inclusion and exclusion criteria were applied to the 46 full-text articles. Finally, 8 articles that met the predefined criteria were included in the systematic review (Figure 1).

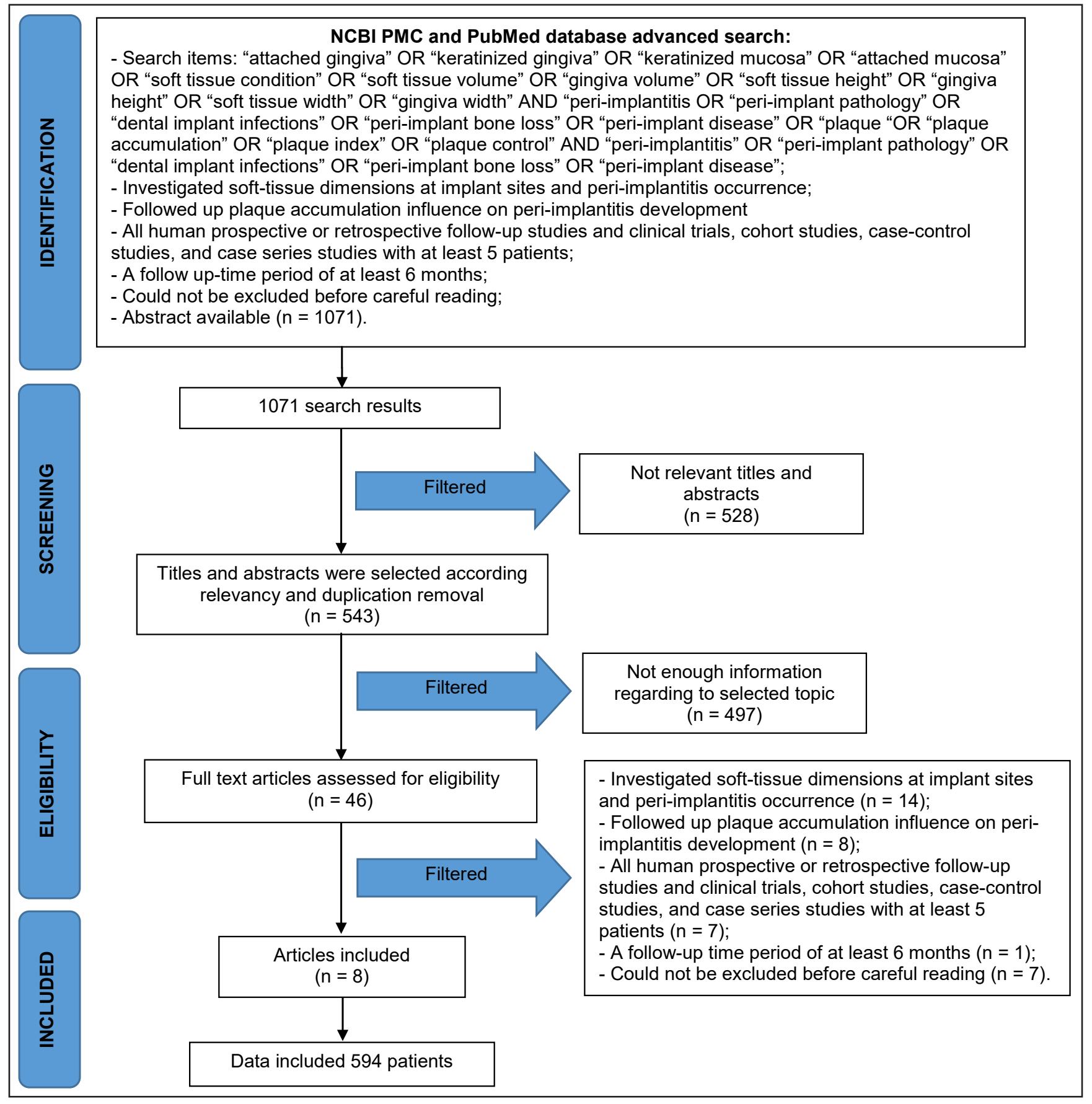

Figure 1. Procedural flow of the literature search and selection process. 
Five of them are prospective clinical studies (patients number: 287; implants number: 917), one crosssectional study (patients: 109; implants: 202), one retrospective study (patients: 118; implants: 320 ) and one present cohort study (patients: 80; implants: 270). Total patients number: 594; total implants number: 1709.

\section{Exclusion of studies}

The reasons for excluding studies after full-text assessment were as follows: investigated soft-tissue dimensions at implant sites and peri-implantitis occurrence $(\mathrm{n}=14)$, followed-up plaque accumulation influence on peri-implantitis development $(n=8)$, all human prospective or retrospective follow-up studies and clinical trials, cohort studies, case-control studies, and case series studies with at least 5 patients $(n=7)$, a follow-up time period of at least 6 months $(n=1)$, could not be excluded before careful reading $(n=7)$.

\section{Study characteristics}

The included studies were further divided into two groups: $\mathrm{KM} \geq 2 \mathrm{~mm} ; \mathrm{KM}<2 \mathrm{~mm}$. Also studies were compared regarding to the follow-up period, number of the patients, implants number and clinical parameters: plaque index (PI), gingival index (GI), probing depth (PD), bleeding on probing/modified bleeding index $(\mathrm{BoP} / \mathrm{mBI})$.

\section{Synthesis of results}

No meta-analysis could be performed due to the heterogeneity in the study designs and treatment modalities.

\section{Influence of keratinized mucosa}

Peri-implant soft-tissue inflammation, marginal tissue recession, $\mathrm{PD}$, and attachment level are the clinical parameters commonly used for monitoring soft-tissue status of dental implants [20]. The clinical signs of $\mathrm{BoP}$, mucosal recession, increasing $\mathrm{PD}$, and loss of attachment level are always present with peri-implant disease [21].

Qualitative change of soft tissue, PI, GI, PD, bleeding index (BI), or BoP were used to determine the status of soft tissue inflammation (Table 1).

- PI: 6 of 8 studies showed significantly higher difference in the PI of the periimplant soft tissues [22-27].

- GI: four clinical studies reported [22-25] higher scores of GI in implants with narrow keratinized mucosa $(<2 \mathrm{~mm})$.

- PD: 2 of 8 studies showed significantly smaller PD at implants with $\geq 2 \mathrm{~mm}$ width of keratinized mucosa $[\underline{22}, \underline{23}]$.

- $\mathrm{BI} / \mathrm{BoP}$ : using $\mathrm{BI} / \mathrm{BoP}$ as an indicator of the presence of an inflammatory lesion in the peri-implant mucosa, 3 of 8 studies showed significantly higher prevalence of bleeding scores at implants with $<2 \mathrm{~mm}$ compared to $\geq 2 \mathrm{~mm}$ width of keratinized mucosa [24, $\underline{26}, \underline{27}]$.

However, other studies showed that the width of keratinized mucosa around implants had no impact on PI, GI, PD and BI/BoP. The findings of those studies regarding the effect of the width of keratinized mucosa on soft-tissue inflammation are controversial, and impaired oral hygiene may play a role in the manifestation of mucosal inflammation around implants with minimal keratinized tissue. Several authors reported that significant elevation of GI and BI scores was accompanied by compromised plaque control at sites with narrow keratinized mucosa [2225]. These results demonstrated that the amount of keratinized mucosa has little influence on soft-tissue inflammation in the presence of good oral hygiene. However, suboptimal oral hygiene due to difficulty in access for plaque control in the areas of minimal keratinized mucosa may lead to greater tissue damage. For the maintenance of soft-tissue health of dental implants, the capability to access oral hygiene at implant sites is more important than the width of keratinized mucosa.

\section{Quality assessment}

The quality assessment of the included studies revealed an unknown risk of bias (for one or more key domains) for the majority of the included studies [21$25,27,28]$, one study [26] was classified as low risk (of bias for all key domains) (Table 2).

\section{DISCUSSION}

Traditionally, the sufficient keratinized gingiva has been recognized to maintain healthy gingival tissues and to prevent gingival recession. Particularly, it has been believed that the success of implants is dependent on the ability of the mucosa endowing the appropriate biologic protective role between the oral environment and the implants [29]. According to several authors [30-32] reported that, in good oral hygiene conditions, the marginal gingiva around implants were clinically healthy, even when no keratinized mucosa was present. 
Table 1. Characteristics of the included studies with report on soft tissue condition around dental implants

\begin{tabular}{|c|c|c|c|c|c|c|c|c|c|c|c|c|c|c|c|c|c|}
\hline \multirow{3}{*}{ Study } & \multirow{3}{*}{$\begin{array}{c}\text { Year of } \\
\text { publication }\end{array}$} & \multirow{3}{*}{$\begin{array}{c}\text { Follow- } \\
\text { up } \\
\text { period }\end{array}$} & \multirow{3}{*}{$\begin{array}{l}\text { Study } \\
\text { design }\end{array}$} & \multirow{3}{*}{$\begin{array}{l}\text { Patients } \\
\text { number }\end{array}$} & \multirow{3}{*}{$\begin{array}{l}\text { Implants } \\
\text { number }\end{array}$} & \multicolumn{2}{|c|}{ PI } & \multirow{3}{*}{ P value } & \multicolumn{2}{|c|}{ GI } & \multirow{3}{*}{ P value } & \multicolumn{2}{|c|}{ PD } & \multirow{3}{*}{ P value } & \multicolumn{2}{|c|}{$\mathrm{BoP} / \mathrm{mBI}$} & \multirow{3}{*}{ P value } \\
\hline & & & & & & $\begin{array}{c}\mathrm{KM} \geq 2 \\
\mathbf{m m}\end{array}$ & $\begin{array}{c}\mathrm{KM}<2 \\
\mathbf{m m}\end{array}$ & & $\begin{array}{c}\mathrm{KM} \geq 2 \\
\mathbf{m m}\end{array}$ & $\begin{array}{c}\mathrm{KM}<\mathbf{2} \\
\mathbf{m m}\end{array}$ & & $\begin{array}{c}\mathrm{KM} \geq 2 \\
\mathbf{m m}\end{array}$ & $\begin{array}{c}\mathrm{KM}<2 \\
\mathbf{m m}\end{array}$ & & $\begin{array}{c}\mathrm{KM} \geq 2 \\
\mathbf{m m}\end{array}$ & $\begin{array}{c}\mathbf{K M}<\mathbf{2} \\
\mathbf{m m}\end{array}$ & \\
\hline & & & & & & \multicolumn{2}{|c|}{ Mean (SD) } & & \multicolumn{2}{|c|}{ Mean (SD) } & & \multicolumn{2}{|c|}{ Mean (SD) } & & \multicolumn{2}{|c|}{ Mean (SD) } & \\
\hline $\begin{array}{l}\text { Boynuegri et al. } \\
{[21]}\end{array}$ & 2012 & 1 year & \begin{tabular}{|c|} 
Prospective \\
clinical study
\end{tabular} & 15 & 36 & $0.05(0.19)$ & $0.28(0.38)$ & $<0.05$ & $0.07(0.26)$ & $0.58(0.6)$ & $<0.05$ & & & & $0,24(0,3)$ & $0,39(0,36)$ & $>0.05$ \\
\hline Chung et al. [22] & 2006 & $>3$ years & \begin{tabular}{|c|} 
Prospective \\
clinical study
\end{tabular} & 69 & 339 & $1.26(0.05)$ & $1.51(0.09)$ & $<0.05$ & $0.76(0.04)$ & $0.94(0.07)$ & $<0.05$ & $2.9(0.05)$ & $2.85(0.06)$ & $>0.05$ & $0.54(0.09)$ & $0.43(0.08)$ & $>0.05$ \\
\hline Adibrad et al. [23] & 2009 & 2 years & $\begin{array}{c}\text { Prospective } \\
\text { clinical study }\end{array}$ & 27 & 66 & $1.2(0.71)$ & $1.87(0.59)$ & 0.02 & $1.01(0.67)$ & $1.65(0.78)$ & 0.01 & $2.98(0.51)$ & $3.11(0.56)$ & 0.115 & $0.38(0.34)$ & $0.49(0.3)$ & 0.04 \\
\hline Bouri et al. [24] & 2008 & 1 year & $\begin{array}{c}\text { Prospective } \\
\text { clinical study }\end{array}$ & 76 & 200 & $1.25(0.53)$ & $1.78(0.78)$ & $<0.001$ & $0.91(0.72)$ & $1.5(0.77)$ & $<0.001$ & $3.72(0.75)$ & $3.87(0.66)$ & 0.132 & & & \\
\hline $\begin{array}{l}\text { Romanos et al. } \\
{[25]}\end{array}$ & 2015 & $\begin{array}{l}>2.6 \\
\text { years }\end{array}$ & $\begin{array}{c}\text { Retrospective } \\
\text { study }\end{array}$ & 118 & 320 & $0.45(0.56)$ & $0.69(0.63)$ & 0.001 & & & & & & & $0.11(0.31)$ & $0.31(0.52)$ & $<0.0001$ \\
\hline Souza et al. [26] & 2015 & 1 year & \begin{tabular}{|c|} 
Present \\
cohort study
\end{tabular} & 80 & 270 & $0.6(0.51)$ & $0.92(0.52)$ & 0.008 & & & & $2.36(0.41$ & $2.43(0.65)$ & 0.582 & $51(27.2) \%$ & $63.8(29.3) \%$ & 0.033 \\
\hline Kim et al. [31] & 2009 & $\begin{array}{c}13 \\
\text { months }\end{array}$ & $\begin{array}{c}\text { Prospective } \\
\text { clinical study }\end{array}$ & 100 & 276 & $0.74(0.83)$ & $0.74(0.91)$ & 0.943 & $0.38(0.66)$ & $0.44(0.72)$ & 0.472 & $2.84(1.8)$ & $2.62(1.55)$ & 0.328 & & & \\
\hline Esper et al. [32] & 2012 & 1 year & \begin{tabular}{|c|} 
Cross- \\
sectional \\
study
\end{tabular} & 109 & 202 & $0.6(0.62)$ & $0.67(0.71)$ & 0.487 & $1.25(0.61)$ & $1.11(0.58)$ & 0.127 & $3.02(1.05)$ & $2.43(1.02)$ & $<0.001$ & & & \\
\hline
\end{tabular}

$\mathrm{PI}=$ plaque index $; \mathrm{GI}=$ gingival index $; \mathrm{PD}=$ pocket depth $; \mathrm{BoP} / \mathrm{mBI}=$ bleeding on probing $/$ modified bleeding index; $\mathrm{SD}=$ standard deviation .

Table 2. Bias summary

\begin{tabular}{l|c|c|c|c|c|c|c}
\hline \multicolumn{1}{c|}{ Study } & $\begin{array}{c}\text { Year of } \\
\text { publication }\end{array}$ & $\begin{array}{c}\text { Random } \\
\text { sequence } \\
\text { generation }\end{array}$ & $\begin{array}{c}\text { Allocation } \\
\text { concealment }\end{array}$ & $\begin{array}{c}\text { Blinding of } \\
\text { outcome } \\
\text { assessment }\end{array}$ & $\begin{array}{c}\text { Incomplete } \\
\text { outcome } \\
\text { data }\end{array}$ & $\begin{array}{c}\text { Selective } \\
\text { reporting }\end{array}$ & $\begin{array}{c}\text { Other } \\
\text { sources of } \\
\text { bias }\end{array}$ \\
\hline Boynuegri et al. [21] & 2012 & $?$ & $?$ & $?$ & + & + & + \\
\hline Chung et al. [22] & 2006 & $?$ & $?$ & + & + & + \\
\hline Adibrad et al. [23] & 2009 & $?$ & $?$ & + & + & + \\
\hline Bouri et al. [24] & 2008 & + & $?$ & + & + & + \\
\hline Romanos et al. [25] & 2015 & $?$ & $?$ & + & + & + \\
\hline Souza et al. [26] & 2015 & + & + & + & + & + \\
\hline Kim et al. [31] & 2009 & $?$ & $?$ & $?$ & + & + \\
\hline Esper et al. [32] & 2012 & $?$ & $?$ & + & + & + \\
\hline
\end{tabular}

$+=$ low risk; ? = unclear risk; - = high risk. 
On the other hand more investigators [20-27] with newer data reported an association between implant survival and width of keratinized gingival.

In our findings, some researches [24,26,27] showed that implants with narrow zones of keratinized gingiva had more BoP. In the peri-implant sulcus, the collagen fibers are orientated parallel to the implant surface, in contrast to the collagen fibers adjacent to the natural teeth, which are perpendicularly orientated and anchored in the cementum. The absence of these horizontal collagen fibers will result in less resistance on probing. This will lead to a local tissue trauma and some bleeding, even in clinically healthy peri-implant tissue [19].

We did not find any correlation between KM widths and PD. Our finding is supported by previous studies [23-26,32] that showed that KM width was positively correlated to PD. It was reported that at sites with healthy mucosa or mucositis, the tip of the probe may identify the location of the apical level of the barrier epithelium [33]. At sites with peri-implantitis, however, the probe will penetrate apical to the epithelium and reach the base of the inflammatory lesion at the alveolar bone crest. Consequently, an increased probing depth will result. Schou et al. [34] reported that probing depth measurements at implant and teeth yielded different information, and small alterations in probing depth at implants may reflect changes in soft tissue inflammation rather than loss of supporting tissues.

This study showed that implants with narrow zones of keratinized tissue $(<2 \mathrm{~mm})$ had significantly more plaque and signs of inflammation than those with wider zones of keratinized gingiva $(\geq 2 \mathrm{~mm})$. These findings are supported by previous studies [22,2527] that demonstrated that the absence of adequate keratinized mucosa in endosseous dental implants, especially in posterior implants, was associated with higher plaque accumulation and gingival inflammation. In fact, good oral hygiene is very difficult to achieve around dental restorations without the protection of a band of keratinized gingival tissue. Therefore, in order to achieve long-term stable periimplant health, it is important to achieve an adequate soft tissue seal around dental implant/restorations [35]. Several studies $[\underline{36}, \underline{37}]$ have shown the use of free soft tissue grafts to augment keratinized gingiva in conjunction with implant placement, around present dental implant or following the restoration of an implant. The rationale for performing the procedures include making plaque control more effective, facilitating impression taking by the restorative dentist and dissipating muscular and frenal pull, and possibly preventing further recession $[38,39]$.

In conclusion, the present study demonstrated that patients with $<2 \mathrm{~mm}$ of $\mathrm{KM}$ exhibited higher levels of peri-implant discomfort during brushing, plaque, and peri-implant inflammation. Further studies are necessary to evaluate whether patients reporting brushing discomfort at implant sites are more likely to develop peri-implantitis.

\section{CONCLUSIONS}

This systematic review has highlighted a number of studies examining the clinical relevance of keratinized mucosa around dental implants in preventing periimplant disease. All studies concluded that the width of keratinized mucosa around dental implants was related with less mucosal inflammation, less plaque accumulation, increased stability of the peri-implant area, and prevention of mucosal recession leading to loss of implant.

Within the limitations of the current review, the following conclusions may be drawn:

1. The absence of adequate keratinized mucosa around implants supporting overdentures was associated with higher plaque accumulation, gingival inflammation and bleeding on probing.

2. Only one study reported that in cases with insufficient keratinized gingiva in the vicinity of implants, the insufficiency does not necessarily mediate adverse effects on the hygiene management and soft tissue health condition.

\section{ACKNOWLEDGMENTS AND DISCLOSURE STATEMENTS}

The authors declare that there are no financial or other conflicts of interest related to this publication.

\section{REFERENCES}

1. Preshaw PM, Seymour RA, Heasman PA. Current concepts in periodontal pathogenesis. Dent Update. 2004 Dec;31(10):570-2, 574-8. [Medline: 15656071]

2. Loesche WJ, Grossman NS. Periodontal disease as a specific, albeit chronic, infection: diagnosis and treatment. Clin Microbiol Rev. 2001 Oct;14(4):727-52, table of contents. Review. [Medline: 11585783] [PMC free article: 89001$]$ [doi: 10.1128/CMR.14.4.727-752.2001] 
3. American Academy of Periodontology. Position paper: epidemiology of periodontal diseases. American Academy of Periodontology. J Periodontol. 1996 Sep;67(9):935-45. Review. [Medline: 8884652]

4. Al-Zahrani MS, Bissada NF, Borawskit EA. Obesity and periodontal disease in young, middle-aged, and older adults. J Periodontol. 2003 May;74(5):610-5. [Medline: 12816292] [doi: 10.1902/jop.2003.74.5.610]

5. Ong CT, Ivanovski S, Needleman IG, Retzepi M, Moles DR, Tonetti MS, Donos N. Systematic review of implant outcomes in treated periodontitis subjects. J Clin Periodontol. 2008 May;35(5):438-62. [Medline: 18433385] [doi: 10.1111/j.1600-051X.2008.01207.x]

6. Roos-Jansåker AM, Lindahl C, Renvert H, Renvert S. Nine- to fourteen-year follow-up of implant treatment. Part II: presence of peri-implant lesions. J Clin Periodontol. 2006 Apr;33(4):290-5. [Medline: 16553638] [doi: 10.1111/j.1600-051X.2006.00906.x]

7. Mombelli A, Lang NP. The diagnosis and treatment of peri-implantitis. Periodontol 2000. 1998 Jun;17:63-76. [Medline: 10337314] [doi: 10.1111/j.1600-0757.1998.tb00124.x]

8. Schätzle M, Faddy MJ, Cullinan MP, Seymour GJ, Lang NP, Bürgin W, Anerud A, Boysen H, Löe H. The clinical course of chronic periodontitis: V. Predictive factors in periodontal disease. J Clin Periodontol. 2009 May;36(5):365-71. [Medline: 19419434] [doi: 10.1111/j.1600-051X.2009.01391.x]

9. Hugoson A, Norderyd O. Has the prevalence of periodontitis changed during the last 30 years? J Clin Periodontol. 2008 Sep;35(8 Suppl):338-45. [Medline: 18724861] [doi: 10.1111/j.1600-051X.2008.01279.x]

10. McKinney RV Jr, Steflick DE, Koth DL, Singh BB. The scientific basis for dental implant therapy. J Dent Educ. 1988 Dec;52(12):696-705. Review. [Medline: 3057013]

11. Schroeder A, van der Zypen E, Stich H, Sutter F. The reactions of bone, connective tissue, and epithelium to endosteal implants with titanium-sprayed surfaces. J Maxillofac Surg. 1981 Feb;9(1):15-25. [Medline: 6939769]

12. Brånemark PI, Adell R, Breine U, Hansson BO, Lindström J, Ohlsson A. Intra-osseous anchorage of dental prostheses. I. Experimental studies. Scand J Plast Reconstr Surg. 1969;3(2):81-100. [Medline: 4924041]

13. Frisch E, Ziebolz D, Vach K, Ratka-Krüger P. The effect of keratinized mucosa width on peri-implant outcome under supportive postimplant therapy. Clin Implant Dent Relat Res. 2015 Jan;17 Suppl 1:e236-44. [Medline: 24341796] [doi: $10.1111 /$ cid.12187]

14. Pontoriero R, Tonelli MP, Carnevale G, Mombelli A, Nyman SR, Lang NP. Experimentally induced periimplant mucositis. A clinical study in humans. Clin Oral Implants Res. 1994 Dec;5(4):254-9. [Medline: 7640340] [doi: $10.1034 / j .1600-0501.1994 .050409 . x$ ]

15. Fürst MM, Salvi GE, Lang NP, Persson GR. Bacterial colonization immediately after installation on oral titanium implants. Clin Oral Implants Res. 2007 Aug;18(4):501-8. [Medline: 17501978] [doi: 10.1111/j.1600-0501.2007.01381.x]

16. Quirynen M, Vogels R, Pauwels M, HaffajeeAD, Socransky SS, Uzel NG, van Steenberghe D. Initial subgingival colonization of 'pristine' pockets. J Dent Res. 2005 Apr;84(4):340-4. [Medline: 15790740] [doi: 10.1177/154405910508400409]

17. Quirynen M, Vogels R, Peeters W, van Steenberghe D, Naert I, Haffajee A. Dynamics of initial subgingival colonization of 'pristine' peri-implant pockets. Clin Oral Implants Res. 2006 Feb;17(1):25-37. [Medline: 16441782] [doi: 10.1111/j.1600-0501.2005.01194.x]

18. Liberati A, Altman DG, Tetzlaff J, Mulrow C, Gøtzsche PC, Ioannidis JP, Clarke M, Devereaux PJ, Kleijnen J, Moher D. The PRISMA statement for reporting systematic reviews and meta-analyses of studies that evaluate health care interventions: explanation and elaboration. J Clin Epidemiol. 2009 Oct;62(10):e1-34. [Medline: 19631507] [doi: 10.1016/j.jclinepi.2009.06.006]

19. Higgins JPT, Altman DG, Sterne JAC. Chapter 8: assessing risk of bias in included studies. In: Higgins JPT, Green S, editors. Cochrane handbook for systematic reviews of interventions version 5.1.0 (updated March 2011). The Cochrane Collaboration. 2011. [URL: http://handbook.cochrane.org/chapter_8/8 assessing_risk of bias in included_studies. $\underline{\mathrm{htm}}]$

20. Salvi GE, Lang NP. Diagnostic parameters for monitoring peri-implant conditions. Int J Oral Maxillofac Implants. 2004;19 Suppl:116-27. Review. [Medline: 15635952]

21. Heitz-Mayfield LJ. Peri-implant diseases: diagnosis and risk indicators. J Clin Periodontol. 2008 Sep;35(8 Suppl): 292-304. Review. [Medline: 18724857] [doi: 10.1111/j.1600-051X.2008.01275.x]

22. Boynueğri D, Nemli SK, Kasko YA. Significance of keratinized mucosa around dental implants: a prospective comparative study. Clin Oral Implants Res. 2013 Aug;24(8):928-33. [Medline: 22540356] [doi: 10.1111/j.1600-0501.2012.02475.x]

23. Chung DM, Oh TJ, Shotwell JL, Misch CE, Wang HL. Significance of keratinized mucosa in maintenance of dental implants with different surfaces. J Periodontol. 2006 Aug;77(8):1410-20. [Medline: 16881810] [doi: 10.1902/jop.2006.050393]

24. Adibrad M, Shahabuei M, Sahabi M. Significance of the width of keratinized mucosa on the health status of the supporting tissue around implants supporting overdentures. J Oral Implantol. 2009;35(5):232-7. [Medline: 19882819] [doi: 10.1563/AAID-JOI-D-09-00035.1]

25. Bouri A Jr, Bissada N, Al-Zahrani MS, Faddoul F, Nouneh I. Width of keratinized gingiva and the health status of the supporting tissues around dental implants. Int J Oral Maxillofac Implants. 2008 Mar-Apr;23(2):323-6. [Medline: 18548930] 
26. Romanos G, Grizas E, Nentwig GH. Association of Keratinized Mucosa and Periimplant Soft Tissue Stability Around Implants With Platform Switching. Implant Dent. 2015 Aug;24(4):422-6. [Medline: 26200163] [doi: 10.1097/ID.0000000000000274]

27. Souza AB, Tormena M, Matarazzo F, Araújo MG. The influence of peri-implant keratinized mucosa on brushing discomfort and peri-implant tissue health. Clin Oral Implants Res. 2016 Jun;27(6):650-5. [Medline: 26474541] [doi: $10.1111 / \mathrm{clr} .12703$ ]

28. Park JB. Increasing the width of keratinized mucosa around endosseous implant using acellular dermal matrix allograft. Implant Dent. 2006 Sep;15(3):275-81. [Medline: 16966901] [doi: 10.1097/01.id.0000227078.70869.20]

29. Ten Cate AR. The gingival junction. In: Branemark PI, Zarb GA, Albrektsson T, editors. Tissue Integrated Prostheses. Chicago: Qunitessence; 1985. pp. 145-53.

30. Schou S, Holmstrup P, Hjørting-Hansen E, Lang NP. Plaque-induced marginal tissue reactions of osseointegrated oral implants: a review of the literature. Clin Oral Implants Res. 1992 Dec;3(4):149-61. [Medline: 1298429] [doi: 10.1034/j.1600-0501.1992.030401.x]

31. Wennström JL, Bengazi F, Lekholm U. The influence of the masticatory mucosa on the peri-implant soft tissue condition. Clin Oral Implants Res. 1994 Mar;5(1):1-8. [Medline: 8038340] [doi: 10.1034/j.1600-0501.1994.050101.x]

32. Kim BS, Kim YK, Yun PY, Yi YJ, Lee HJ, Kim SG, Son JS. Evaluation of peri-implant tissue response according to the presence of keratinized mucosa. Oral Surg Oral Med Oral Pathol Oral Radiol Endod. 2009 Mar;107(3):e24-8. [Medline: 19217009 ] [doi: $\underline{10.1016 / \text { j.tripleo.2008.12.010] }}$

33. Esper LA, Ferreira SB Jr, Kaizer Rde O, de Almeida AL. The role of keratinized mucosa in peri-implant health. Cleft Palate Craniofac J. 2012 Mar;49(2):167-70. [Medline: 21417779] [doi: 10.1597/09-022]

34. Schou S, Holmstrup P, Stoltze K, Hjørting-Hansen E, Fiehn NE, Skovgaard LT. Probing around implants and teeth with healthy or inflamed peri-implant mucosa/gingiva. A histologic comparison in cynomolgus monkeys (Macaca fascicularis). Clin Oral Implants Res. 2002 Apr;13(2):113-26. [Medline: 11952731] [doi: 10.1034/j.1600-0501.2002.130201.x]

35. Yeung SC. Biological basis for soft tissue management in implant dentistry. Aust Dent J. 2008 Jun;53 Suppl 1:S39-42. [Medline: 18498584] [doi: 10.1111/j.1834-7819.2008.00040.x]

36. Han TJ, Klokkevold PR, Takei HH. Strip gingival autograft used to correct mucogingival problems around implants. Int J Periodontics Restorative Dent. 1995 Aug;15(4):404-11. [Medline: 8593990]

37. Poskevicius L, Sidlauskas A, Galindo-Moreno P, Juodzbalys G. Dimensional soft tissue changes following soft tissue grafting in conjunction with implant placement or around present dental implants: a systematic review. Clin Oral Implants Res. 2015 May 5. [Medline: 25939960] [doi: 10.1111/clr.12606]

38. Covani U, Marconcini S, Galassini G, Cornelini R, Santini S, Barone A. Connective tissue graft used as a biologic barrier to cover an immediate implant. J Periodontol. 2007 Aug;78(8):1644-9. [Medline: 17668986] [doi: $10.1902 /$ jop.2007.060461]

39. Park JB. Increasing the width of keratinized mucosa around endosseous implant using acellular dermal matrix allograft. Implant Dent. 2006 Sep;15(3):275-81. [Medline: 16966901] [doi: 10.1097/01.id.0000227078.70869.20]

\section{To cite this article:}

Pranskunas M, Poskevicius L, Juodzbalys G, Kubilius R, Jimbo R.

Influence of Peri-Implant Soft Tissue Condition and Plaque Accumulation on Peri-Implantitis: a Systematic Review

J Oral Maxillofac Res 2016;7(3):e2

URL: http://www.ejomr.org/JOMR/archives/2016/3/e2/v7n3e2.pdf

doi: $10.5037 /$ jomr.2016.7302

Copyright (C) Pranskunas M, Poskevicius L, Juodzbalys G, Kubilius R, Jimbo R. Published in the JOURNAL OF ORAL \& MAXILLOFACIAL RESEARCH (http://www.ejomr.org), 9 September 2016.

This is an open-access article, first published in the JOURNAL OF ORAL \& MAXILLOFACIAL RESEARCH, distributed under the terms of the Creative Commons Attribution-Noncommercial-No Derivative Works 3.0 Unported License, which permits unrestricted non-commercial use, distribution, and reproduction in any medium, provided the original work and is properly cited. The copyright, license information and link to the original publication on (http://www.ejomr.org) must be included. 